\title{
MASJID JAMI KALI PASIR: IN BETWEEN 'MYTH' AND A NEED FOR HISTORICAL ACCURACY
}

\author{
F. HENDOLA \& A.J. PRIADI \\ Department of Architecture, Universitas Pembangunan Jaya, Indonesia.
}

\begin{abstract}
Since 2011, Masjid Jami Kali Pasir (Kali Pasir Mosque) has been legitimated as an architectural heritage by the government of Tangerang city, West Java, Indonesia. It is located at the heritage site of Pasar Lama-Kali Pasir where Chinese settlements are also present. There are a few opinions that consider the mosque has Chinese architectural style, which was used to 'mingle' with Chinese settlements near it. However, lack of accurate historical documentation of Masjid Jami Kali Pasir makes those assumptions questionable. Moreover, despite its style and history, Masjid Jami Kali Pasir is hard to be recognized because it is hidden in between houses. On this basis, this article is an attempt to know how Masjid Jami Kali Pasir impacts on the characteristic of Pasar Lama-Kali Pasir heritage site from an architectural and urban design point of view. By exploring the mosque's architecture and spatial conditions around it, we acknowledge how significant its presence is to be preserved although it lacks a valid historical data. We analyse the urban structure of Pasar Lama-Kali Pasir area to know its characteristic.

We also observe Masjid Jami Kali Pasir's latest condition to search if there is any common physical appearance between the mosque and its surroundings. Then we figure how the 'myth' about the mosque occurred. From the observations and analysis, we assume that the 'myth' about the mosque plays an important role in making Masjid Jami Kali Pasir significant as a heritage site.
\end{abstract}

Keywords: Chinese architecture, heritage, historic building, Islam architecture, mosque, myth, preservation.

\section{INTRODUCTION}

Bernard Feilden [1], a conservation architect, once wrote, ' $\ldots$ an historic building is one that gives us a sense of wonder ... it has architectural, aesthetic, historic documentary, archaeological, economic, social and even political and spiritual or symbolic values; but the first impact is always emotional'. Because of its potential effect of inspiring people who experience its architectural element, a historic building becomes one of the most significant urban features in a city. This is also one of the reasons why we have to preserve it.

However, categorizing buildings as historic is often problematic. In Indonesia, the term 'bangunan cagar budaya' or 'heritage building' is used more often than 'bangunan bersejarah' - 'historic building'. The term 'heritage' indicates that the building has to be valued as an important 'inheritance' to be conserved. According to the regulation of Indonesia's Ministry of Public Works and Housings number 01/PRT/M/2015 about preservation of heritage buildings [2], a building is considered conservable if it is required to be heirlooms. This also means that the validity of historic document is important to value its originality and current presence for further generation, especially in inheriting some cultural, spiritual or national value.

Regarding that regulation, Masjid Jami Kali Pasir (Kali Pasir Mosque), as a legitimated heritage building since 2011 [3], on the contrary, lacks valid historical data and documentation. Head of the board of Masjid Jami Kali Pasir's welfare once met and told us that

This paper is part of the Proceedings of the International Conference on Islamic Heritage Architecture and Art (Islamic Heritage Architecture 2016)

www.witconferences.com 


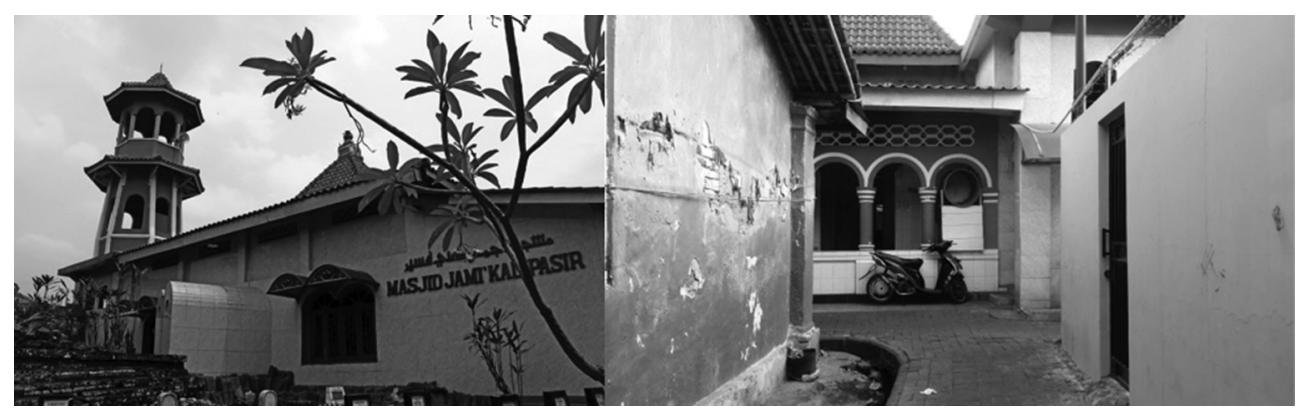

Figure 1: Masjid Jami Kali Pasir (left) and access to the Masjid (right).

evidences about the mosque's history were questionable. He even said that he did not have any written proof about it, except a note on a piece of paper.

Furthermore, Masjid Jami Kali Pasir's appearance is insignificant if it is compared with BoenTek Bio, a Chinese temple at Pasar Lama. Nevertheless, the similarities between both religious buildings and some ornaments have created the opinion about religious tolerance and diversity at Pasar Lama-Kali Pasir area. There are even several online articles saying that the mosque 'shows reconciliation and acculturation of local culture, Arabic culture and Chinese culture' [4] (Fig. 1).

The questionable legitimacy and rumours about Masjid Jami Kali Pasir have become triggers for us to ask, 'How does Masjid Jami Kali Pasir give impact to the characteristic of Pasar LamaKali Pasir as a heritage site?' Instead of collecting its accurate historical document, which might be inconsequential, we focus our search on the mosque's architectural elements. To answer the question, firstly, we try to figure the urban characteristic of Pasar Lama-Kali Pasir heritage site by analysing its urban structure. Secondly, we analyse Masjid Jami Kali Pasir's (latest) architectural elements, observing activities inside and around it and analysing the semiotic system beneath it. The answer to the question will lead us to other architectural aspects besides its valid documentary that shall be considered in preserving a presumable historic building.

\section{THE URBAN CHARACTERISTIC OF PASAR LAMA-KALI PASIR}

As we have explained earlier, we start our analysis by examining the urban characteristic of Pasar Lama-Kali Pasir. This site is famously known as the old town of Tangerang, but we specify the area by literally using 'Pasar Lama-Kali Pasir' to emphasize our scope of observation. The term 'Pasar Lama' is often referred to the commercial strip at Jalan Kisamaun where many vendors sell various kinds of traditional and modern food. The variety of food and the feel of past time that are represented on some old buildings have attracted many visitors. Meanwhile 'Kali Pasir' is bounded by Jalan Kali Pasir Indah - a street abreast along Cisadane River. The street is not as crowded as Jalan Kisamaun but it has the river as its own attraction. The riverbank has been developed into a sidewalk that is wide enough for vendors to sell food and beverage. Our observation for this article focuses on the area in between both streets. It is dominated by settlements but not separated from the commercial area as its surrounding has become vibrant for its trades (Fig. 2).

Not only is Pasar Lama-Kali Pasir lively, but it is also known as one of the places where Cina Benteng - half-blood Chinese of Benteng ('fortress' in Bahasa Indonesia) - inhabit. A look through the history of Pasar Lama-Kali Pasir will surprise us. A tour guide at Benteng Heritage Museum, a place where basically some Cina Benteng's antiques are collected, 

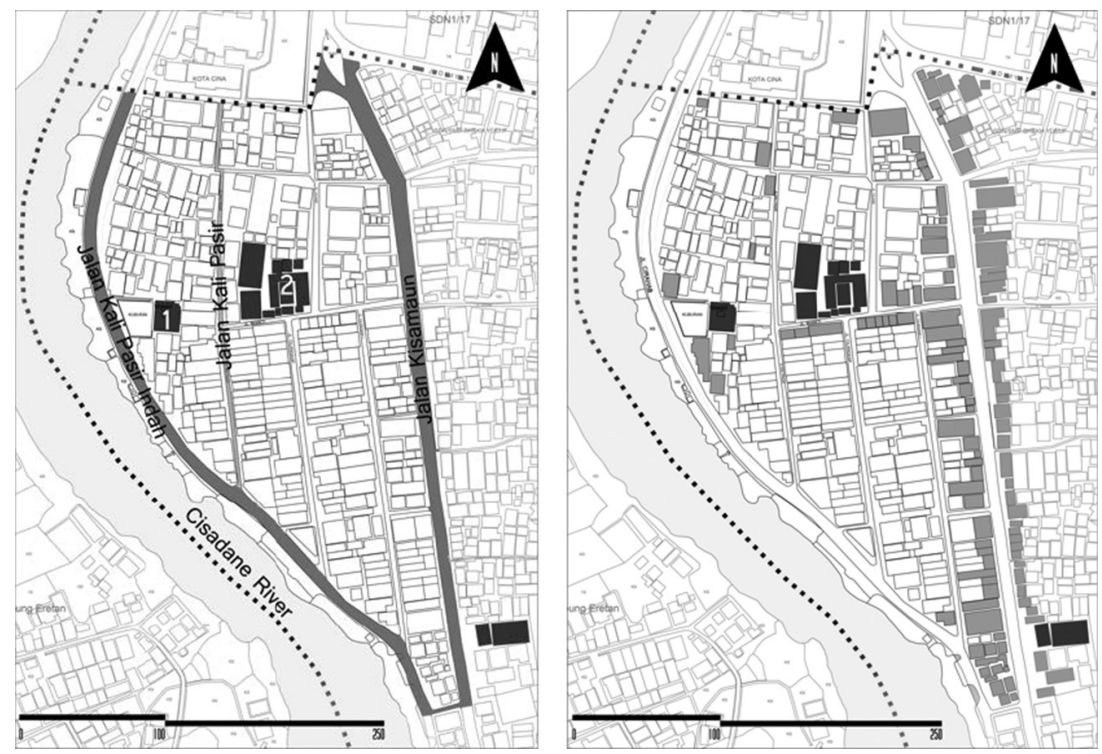

Figure 2: Scope of our observation (1: Masjid Jami Kali Pasir, 2: Boen Tek Bio) and commercial buildings map.

explained that the Chinese first came to Tangerang in $1407 \mathrm{AD}$ and then married the natives. Their half-blood children lived at Tangerang, especially along Cisadane River. The word 'benteng' was coined because in the 1600s VOC (Vereenidge-Oost Indische Compagnie Dutch East India Company), who ruled Batavia (now Jakarta), built fortress at Tangerang to protect it while its relation with Banten hardened [5]. Since then half-blood Chinese who live at Tangerang have been called 'Cina Benteng'.

Although there are many things to learn from Pasar Lama-Kali Pasir area, we align our explanation to specific points. Nahoum Cohen [6] in Urban Planning Conservation and Preservation wrote that there were two major characteristics that a heritage site must have to enhance its uniqueness: aesthetic qualities and historical qualities. Pasar Lama-Kali Pasir area has these qualities reflected on Chinese buildings that are ruined, renovated or even restored and on its urban structure. Both aspects will be explained below.

\subsection{Continuing transformations}

Anyone who visits Pasar Lama-Kali Pasir for the first time will notice that this area has been dominated by Chinese settlement since a long time. Although surrounded by newer buildings, gables of old Chinese houses are conspicuous. Some of the houses are unused while others function as a shop, creating typical Chinese shop houses. This nuance lingers and gets stronger as BoenTek Bio temple is found exactly in front of a T-junction.

In our observation that kind of inspiration also struck us, especially when we finally found Benteng Heritage Museum, which is a restored Chinese building located behind BoenTek Bio. It used to be a house before the occupants decided to move out because of the hustle and bustle of the market in front of their place constantly disturbing them. In 2009 Udaya Halim, an antique enthusiast, bought it and restored it into a museum [7]. Since 2011, the museum 

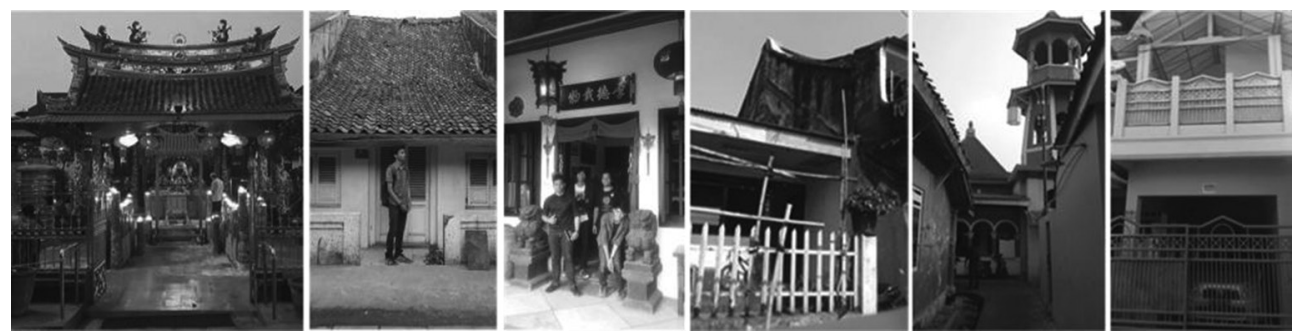

Figure 3: (left to right) Boen Tek Bio temple, an original Chinese house, Benteng Heritage Museum, a 'hybrid' house, Masjid Jami Kali Pasir, a 'contemporary' two-storey house.

has provided information about Cine Benteng for the visitors and given them a hint of old Chinese settlement's nuance.

On the other hand, some sort of 'hybrid' buildings also adorn Pasar Lama-Kali Pasir area. Old gables of Chinese houses are still noticeable even though its facade cannot be assumed as original architecture. Some of them are still being used, while others have been abandoned or even in ruins. However, the gables become an evidence of the past (Fig. 3).

Those buildings - restored or renovated - are of course included to what Cohen called as aesthetic values. It was appealing for us to observe and explore the museum's appearance along BoenTek Bio and other old Chinese buildings near it while witnessing some transformation.

Nevertheless, those are not the only types of buildings that make Pasar Lama-Kali Pasir area unique. We cannot deny that other types of new buildings play a role in creating a distinctiveness for the site. One of them is rumah walet - wallet house. It is a three-to-four storey building that has a massive wallet nest inside it. The wallet houses have dominated the view along Cisadane riverbank. Their plain tall walls have marked the riverbank area. Moreover, there are also 'contemporary' shop houses, which, unlike typical Chinese shop houses, do not have traditional roof or replaces it with a flat roof (Fig. 3). Sadly, this rumah walet and other newer buildings that were built without considering or maintaining Chinese characteristics can reduce the historical values of Pasar Lama-Kali Pasir. This fact shows that transformations of the building continue, albeit Pasar Lama-Kali Pasir area containing such historic buildings to maintain its culture.

\subsection{Two distinct areas}

While the buildings at Pasar Lama-Kali Pasir area show physical transformation of the site, the urban webs represent how diverse it is. If we look at this heritage site from the top we can see two distinct areas: one has grid layout and the other seems random (Fig. 4). In between those two areas there is Jalan Kali Pasir emphasizing each area's peculiarity.

The east side of Jalan Kali Pasir is where Boen Tek Bio and old Chinese houses stand side by side. The grid webs are not unintended. Most Chinese settlements were laid out based on the philosophy of feng shui. So is Pasar Lama area. None of the settlements face north as it is considered bad for residential buildings. Furthermore, according to feng shui, the ideal orientation for houses is in front of a cold area or mountain, facing south or a river which is believed as more prosperous side [8]. In our case, the old Chinese houses are not exactly river 

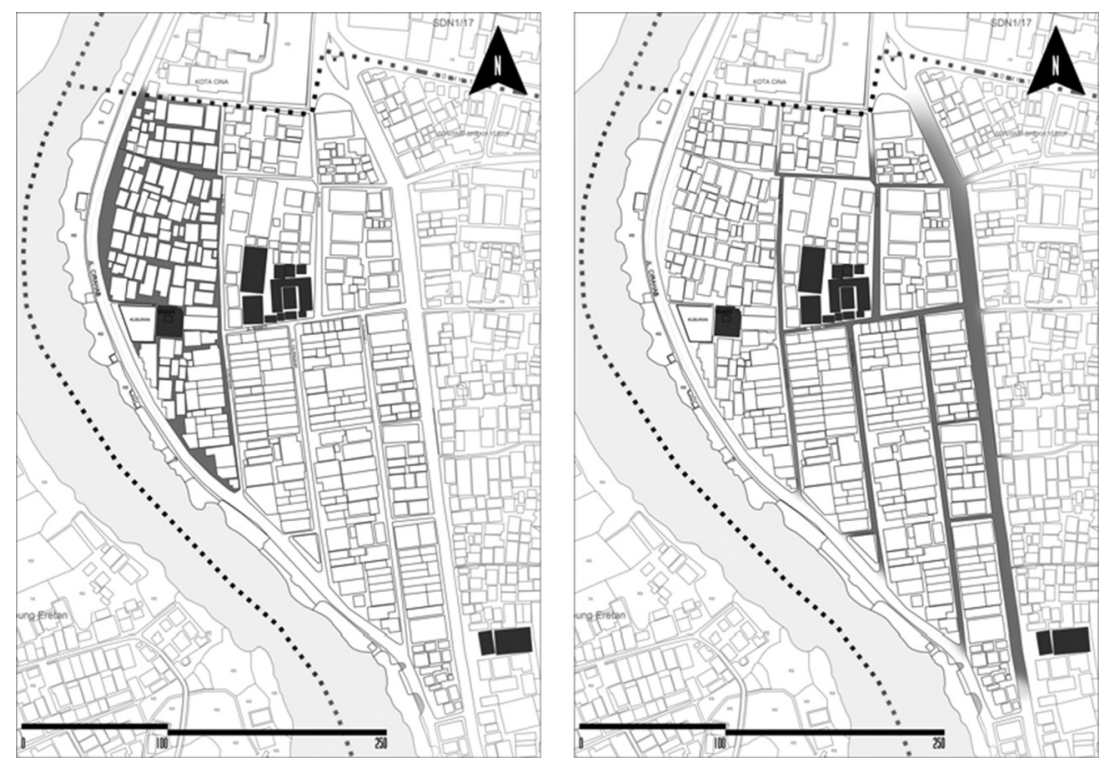

Figure 4: Irregular webs (left) and grid webs (right).

oriented. Cisadane River bends at Pasar Lama-Kali Pasir area and turns it as what is believed by Chinese as ' $q i$ ' - vital energy. Therefore the settlements do not have to follow the river trail. They face west or east with grid webs instead. Moreover, Boen Tek Bio as the sacred place was located exactly in front of T-junction, which is believed as bad omen, to ward bad luck off.

West side of Jalan Kali Pasir is where Masjid Jami Kali Pasir stands up and blends with settlements around it. Walking through the narrow alleys around this area reminded us about one of Jahn Gehl's [9] statement in Cities for People: 'In narrow streets and spall spaces, we can see buildings, details, and the people around us at close range ... we perceive the scene as warm, personal and welcoming.' That was almost exactly what we felt. The alleys are not mere access from one point to another. These corridors are used as social space for residents around this area. Some of them were found in deep conversations in front of their houses while others were buying beverages at vendors and warung small shop. Even though the alleys are narrow, the potential to have social contact is massive.

\subsection{Pasar Lama-Kali Pasir's characteristic: Distinctness creates diversity}

From the observations, we realize that Pasar Lama-Kali Pasir area has 'diverse' character. Considering its etymology, 'diverse' was originally from a Latin word 'diversus', which means 'turned in various directions' [10]. That is what appears at Pasar Lama-Kali Pasir since it contains such different nuances: old buildings with new ones and Chinese houses with non-Chinese ones.

In relation to this feel of diversity, Aldo Rossi wrote, 'One must remember that the difference between past and future, from the point of view of the theory of knowledge, in large measure reflects the fact that the past is partly being experienced now, and this may be the 
meaning to give permanences: they are a past that we are still experiencing' [11]. Its permanency gives a (historic) building a chance to be sensed in present time, with different points of view from its original design principles. This statement reflects on buildings at Pasar LamaKali Pasir area. The hybrid buildings maintain the feel of old time while transformation still continues. As a heritage site, its function and spatial meaning are not always the same. Anyone who observes or visits it will redefine its traces of its past time.

In addition, Jalan Kali Pasir divides the site into two distinct areas: grid web, which reflects feng shui at its east side and irregular web at its west side. Their difference emphasizes the heritage site's diversity. All of these facts are mixed with the vibrancy of commercial activities at Pasar Lama-Kali Pasir area - along the streets and alleys - which then turns Pasar Lama-Kali Pasir to be a peculiar site to visit.

\section{ARCHITECTURE OF MASJID JAMI KALI PASIR}

We have concluded the characteristic of Pasar Lama-Kali Pasir heritage site. Now we have to delve into Masjid Jami Kali Pasir. At this point, we align our explanation about the mosque into three parts: its physical elements, its non-physical elements (including activities inside and around it) and analysis about how 'myth', borrowing Roland Barthes' term, happened and gives impact to the mosque's surrounding.

\subsection{Physical elements of Masjid Jami Kali Pasir}

Masjid Jami Kali Pasir is a small mosque with a cemetery in front of it. Head of the board of Masjid Jami Kali Pasir's welfare said Tumenggung Pamit Wijaya built it in the 1700s. The founder himself was also buried in the cemetery, which then became one of the most protected parts of the mosque.

As a tourist attraction, Masjid Jami Kali Pasir is not as attractive as Boen Tek Bio. The access to the mosque is not easy. As we mentioned earlier, narrow alleys surround Masjid Jami Kali Pasir. Thus, it is hard to observe its wholeness. Practically the minaret is the most noticeable feature of Masjid Jami Kali Pasir but we cannot say that we sensed its grandeur. Walking through the alleys from Jalan Kali Pasir Indah to the mosque did not give us a chance to perceive the minaret as a landmark or splendid feature of the neighbourhood. We noticed it from a distance but as soon as we walked through the alley next to the cemetery in front of it, our sight became narrowed. The only things we saw were the path, wall and fences.

Scale, then, does matter. While the narrow alleys welcome pedestrians to walk through, the architecture of buildings that frame the alleys cannot be enjoyed entirely. We can see details but not the whole building. Hence parts of Masjid Jami Kali Pasir cannot be visually enjoyable altogether. We have to see the minaret first or the roof first, before we can enjoy another part of the mosque.

On the other side, Masjid Jami Kali Pasir as a religious place is more 'humble' compared with Boen Tek Bio. It does not have as many ornaments as the temple. The only catchy ornament is probably the gold lotus on top of the mosque's roof (Fig. 5). It is also one of the oldest parts of Masjid Jami Kali Pasir. Nevertheless, there is no valid document which says why this ornament was put on a kind of religious building that, in Indonesia, is generally symbolized by star and moon ornaments. At the same time, the minaret, which basically has an octagonal shape, is often considered similar to Chinese pagoda. This distinctness makes Masjid Jami Kali Pasir allegedly correlated to Boen Tek Bio as an influencing Chinese building. Even a tour guide of Benteng Heritage Museum stated that the mosque was believed to be influenced by Chinese architecture. 

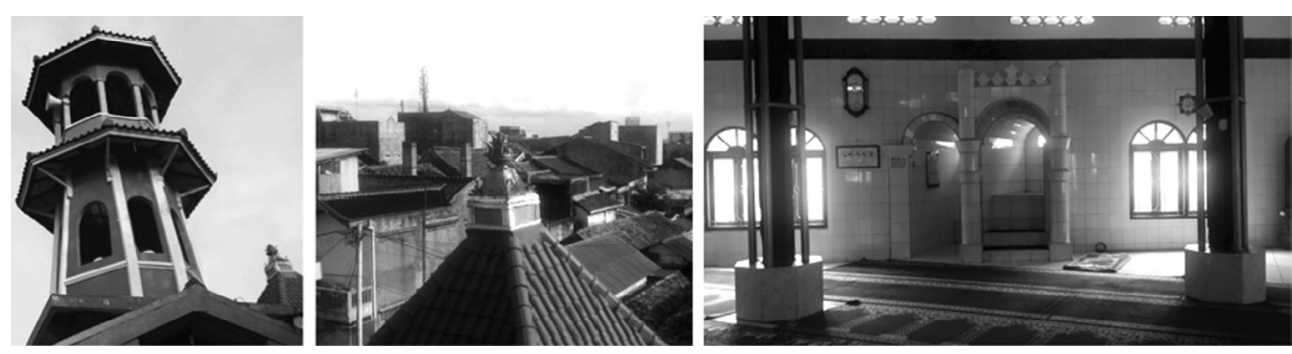

Figure 5: (left to right) The minaret, the gold lotus and interior of Masjid Jami Kali Pasir.

Looking through its interior, Masjid Jami Kali Pasir has rooms dominated by ceramics (Fig. 5). One of the board's members said the ceramic walls were not original parts of the mosque but the four wood columns were. The columns are located in the middle of the mosque, making quite interesting nuance: permanency brings a feel of old time.

From this observation we realized that Masjid Jami Kali Pasir's physical appearance is not significant enough to be a landmark heritage site. It also has several components that are similar to Chinese ornaments. Despite the lack of historical documentary, this similarity makes the mosque easily related to the Chinese settlements. At the same time, the mosque's original parts such as the gold lotus and four wood columns have potential to maintain its historic value.

\subsection{Non-physical elements of Masjid Jami Kali Pasir}

In general a mosque is a place for Muslims to pray. Despite its status as a historic building, Masjid Jami Kali Pasir has the same function, specifically for Muslims who stay in Tangerang. It allows them to daily pray together, read and recite Al-Quran (Islamic holy bible), etc. Even though Muslims are obliged to pray five times a day, a mosque, including Masjid Jami Kali Pasir, is not used only for praying but also other communal activities, such as meetings and preparing for big Islamic events.

Every function in Masjid Jami Kali Pasir can be defined by specific components in the room. For example, praying room is generally marked by sajadah - a carpet for praying - and bookcases for Quran. But specifically, praying room for men has a microphone for the imam while praying room for women has mukenah - specific women's clothes used for praying cases. At the other end there is also a room for wudhu, which has other specific components, such as water faucet, pipes, etc. This room is also connected to the mosque's terrace.

Overall Masjid Jami Kali Pasir is managed and maintained by the board of Masjid Jami Kali Pasir's welfare. The members make sure it is always well protected for both religious activities and communal activities. Size, then, becomes important. Praying room, which is the largest room, can be used for communal activities such as meeting and preparing for big events. Other smaller space such as the mosque's terrace can also support activities inside the mosque. It is usually used for casual conversations between Muslims while some groups pray inside and as a place to store some stuff for religious events. All of these activities are allowed with the board's permission.

Everyone is welcome to visit Masjid Jami Kali Pasir, to pray or even to join the events albeit the board seems ruling it. On last eid al-Mawlid an-Nabawi - Prophet Muhammad's birthday - we joined one of the most famous events of Masjid Jami 

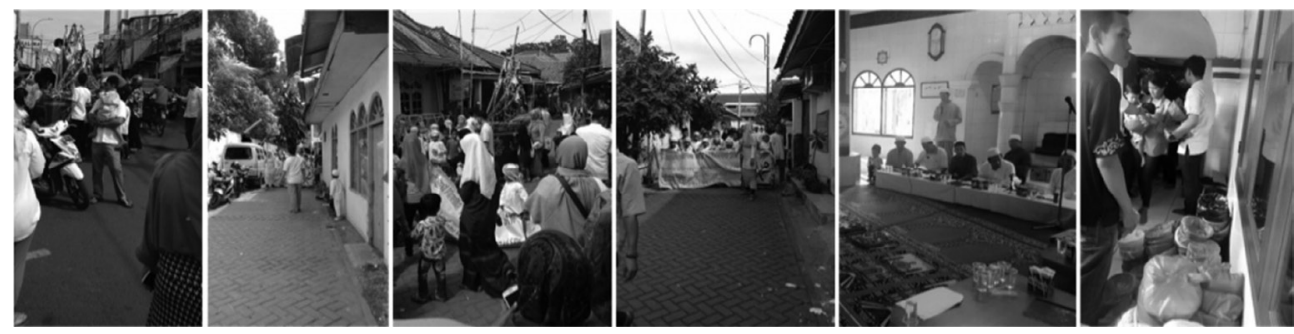

Figure 6: Arakan Perahu.

Kali Pasir: Arakan Perahu - boat marches (Fig. 6). It is an event to celebrate the spread of Islam, which allegedly entered Tangerang from Cisadane River. It is not exactly held in the mosque but Masjid Jami Kali Pasir is the start and finish line of the parade. The march was what Canetti [12] called as an 'open crowd', '... it wants to consist of more people ... it wants to seize everyone within reach; anything shaped like a human being can join it'. Everyone could join it while it marches around Pasar Lama-Kali Pasir area, showing how grateful they were. Because of this regular event, Masjid Jami Kali Pasir affects the heritage site stronger than its physical appearance does.

'Occasion and place will reinforce each other to create a vivid present. The result is an active involvement in the immediate, material world and an enlargement of the self,' wrote Kevin Lynch [13]. We think what he said is implemented at Masjid Jami Kali Pasir. All of these activities that happen in or related to Masjid Jami Kali Pasir create 'sense of occasion'. It does not only give the mosque orientation of time but also signifies its role in creating a memorable time for the people. This 'sense of occasion', in other words, also enhances the mosque's significance at Pasar Lama-Kali Pasir area.

\subsection{The 'Myth': (not a mere) religious tolerance at Pasar Lama Kali Pasir}

Based on the observation of Masjid Jami Kali Pasir's physical and non-physical elements, we can say that the mosque and other Chinese buildings at Pasar Lama area do not have many similarities, except the gold lotus. Moreover, to say the minaret is influenced by Chinese architecture is arbitrary.

As we mentioned in the introduction, some people thought that the architecture of Masjid Jami Kali Pasir represented religious tolerance because it has elements of Chinese architecture or reminds whomever perceives the building about Chinese architecture. Although there is no valid argumentation, these thoughts actually make sense, at least from semiotic realm's point of view.

Roland Barthes [14] mentioned three different terms in semiological system: the signifier, the signified and the sign. Relating to Saussure, what we can consider as signifier is the term of an image while signified is the image itself. For example, the term 'tree' is the signifier of the image of leaves with its branches and roots. This denotative meaning does not stop the semiotic system. Barthes also added the role of sign. Although the image of leaves, branches and roots is signified by 'tree', it does not mean it always 'expresses' the term. The image can have new meaning, turning into a sign, which signifies another concept, for instance 'go green'. Although 'go green' does not always fit with the image of leaves, branches and roots, if people use the image repeatedly to enhance the concept, it becomes a 'myth'. 
In our case, Masjid Jami Kali Pasir has gold lotus ornament on top of its roof. The signifier in this case is the term 'gold lotus ornament' and the signified is the image of gold metals shaped like a flower, which is known as a physical characteristic of Chinese buildings. This is the first level. If we observe the ornament more holistically, we realize that the ornament is a part of the mosque. This acknowledgement - Chinese ornament on a non-Chinese building is the sign ('meaningful' signifier) of 'religious and cultural tolerance'. This is another level of the semiotic system.

The system also works on Masjid Jami Kali Pasir's minaret but with a little 'twist'. Instead of 'minaret' as the signifier of the image of the tower, the tower itself, as a form, is the signifier of the image of pagoda. Its octagonal shape and roof remind the enjoyer of one of the most significant constructions of Chinese architecture even though its function is different to a pagoda. Nevertheless, because of its difference, the minaret becomes the sign of 'religious and cultural tolerance'.

Furthermore, 'deformation' of Masjid Jami Kali Pasir's physical element happens because of its closeness to Chinese settlements and distinct functional differences. Regarding Masjid Jami Kali Pasir's non-physical element, daily activities in the mosque happen without creating any relation to the Chinese settlements. Moslems pray at Masjid Jami Kali Pasir without disturbing the prayers at the temple. This is not only because of the mosque's location, which makes it hidden, but is also because Jalan Kali Pasir has emphasized the boundary for both Chinese settlements (east) and non-Chinese settlements (west). Although the access to Masjid Jami Kali Pasir and its whole presence is almost unnoticeable, people around Pasar LamaKali Pasir area easily note some celebration that is related to Masjid Jami Kali Pasir. Arakan Perahu is one such example. It breaks some habits, such as praying five times a day, and emphasizing Masjid Jami Kali Pasir's presence since it is handled not only around the mosque.

If the new meaning ('religious and cultural tolerance') is repeatedly being used by the society to describe the relation between the mosque and its surrounding, it would become a 'myth'. Barthes [14, p. 128] said, '... it (myth) transforms history into nature ... what causes mythical speech to be uttered is perfectly explicit, but it is immediately frozen into something natural: it is not read as a motive, but as a reason'. Correlating his statement to our case, it has been more than a century that people at Pasar Lama-Kali Pasir area have related their existence to the history of Chinese arrival and Islam being spread at Tangerang. Despite its valid historical documentary, history about Islam and Chinese and even Chinese Muslim has been inherited at this heritage site. In fact, the story has already famously known and emphasized by its physical appearance (the Chinese gables along the temple near the mosque). In this case, people consider a story about religious tolerance as facts - as something that is real instead of as symbolic or semiotic. The 'myth' naturalized the history. It distorts the real story about Chinese and Islam arrival into other meanings, which are seemingly still related to the history. Therefore, it is facile for them (or visitors) to correlate the architecture of Masjid Jami Kali Pasir to the concept of 'religious and cultural tolerance'.

\section{CONCLUDING REMARKS}

So how does Masjid Jami Kali Pasir impact the characteristic of Pasar Lama-Kali Pasir area? As we concluded earlier, Pasar Lama-Kali Pasir area is a diverse heritage site. Although it is apparently dominated by Chinese architecture, this site contains other non-Chinese elements, especially if we look at its urban web. Meanwhile, Masjid Jami Kali Pasir has a distinct function to Chinese buildings near it but is considered as related to them because of its ornaments, creating 'myth' about religious tolerance. This semiotic system makes the mosque to be significant. Thus, even though its presence is visually insignificant, Masjid Jami Kali Pasir 
can mark the differences between non-Chinese settlements and Chinese settlements. In other words, it has potential to enrich the characteristic of Pasar Lama-Kali Pasir area: diversity.

Our findings about how 'myth' works on architecture of Masjid Jami Kali Pasir also pushes us to suggest that conservation architects, government and other heritage enthusiasts consider semiological system in a presumably historic building. Valid documentary is still important, but considering persons who will feel its value, a historic building shall be also seen as a sign container that will be interpreted by them.

\section{ACKNOWLEDGEMENTS}

Work on this article was supported by the Department of Architecture, Universitas Pembangunan Jaya. The authors thank Pandu Ghautama, Aldry Setiawan and Hans Ramadiyansyah for help on the observation, collecting data and reworking the graphic; Board of Masjid Jami Kali Pasir's Welfare who has given valuable time for us in researching historical and architectural value of Masjid Jami Kali Pasir; and Muhammad Damm for wonderful discussions about semiotics that enlightened us in our writing process.

\section{REFERENCES}

[1] Feilden, B.M., Conservation of Historic Buildings, Architectural Press: Oxford, p. 1, 2003.

[2] Indonesia's Ministry of Public Works and Housings 01/PRT/M/2015 on preservation of heritage building 2015, s 2(5)(1).

[3] Pemerintah Kota Tangerang, Retrieved from Situs Resmi Pemerintahan Kota Tangerang, available at http://www.tangerangkota.go.id/9-bangunan-dijadikan-cagar-budaya-kotatangerang, 2011 (accessed 23 October 2015).

[4] Kania, D., Retrieved from detiktravel, available at http://travel.detik.com/read/2013/09 /30/192900/2373622/1025/unik-pecinan-tangerang-punya-masjid-bermenara-pagoda, 2013 (accessed 21 November 2015).

[5] Thamrin, M.Y., 'Sang Naga di Barat Jakarta' in National Geographic, pp. 26-29, February 2014.

[6] Cohen, N., Urban Planning Conservation and Preservation, McGraw-Hill: New York, pp. 62-65, 2001.

[7] Museum Benteng Heritage, Retrieved from Museum Benteng Heritage, available at http://www.bentengheritage.com/ (accessed 26 January 2016).

[8] Pratiwo, Arsitektur Tradisional Tionghoa dan Perkembangan Kota, Penerbit Ombak: Yogyakarta, pp. 20-24, 2010.

[9] Gehl, J., Cities for People, Island Press: Washington, p. 53, 2010.

[10] Partridge, E., Origins: A Short Etymological Dictionary of Modern English, Routledge: London, p. 3981, 2006.

[11] Rossi, A., The Architecture of the City, Oppositions Books: New York, p. 57, 1932.

[12] Canetti, E., Crowds and Power, Continuum: New York, p. 16, 1973.

[13] Lynch, K., Good City Form, MIT Press: Cambridge, MA, p.132, 1981.

[14] Barthes, R., Mythologies, The Noonday Press: New York, pp. 111-114, 1991. 